\title{
The Possible Protective Role of Sesame Oil on Skeletal Muscle Regeneration in Induced Red-Bull Injury: Experimental Study
}

\author{
Original \\ Amany Elsayed Mohammed Hamoud, Rasha AbdelKhalek Attia Radwan \\ Article \\ Departments of Anatomy and Embryology, Faculty of Medicine, Cairo University, Egypt.
}

\begin{abstract}
Background: Energy drinks (Eds), including Red Bull, were introduced to United States markets in 1997. Consumption has increased worldwide mainly consumed by athletes and teenagers as they are seeking for increase their energy level. Seasme oil (SO) has been known to have anti-inflammatory and antioxidant properties.

Aim: The current study was designed to elucidate study the possible protective role of SO on skeletal muscle regeneration in Red Bull experimentally induced injury.

Materials and Methods: Twenty adult albino rats were divided into four groups, control, sham control, $\mathrm{RB}$ and $\mathrm{RB}+\mathrm{SO}$. Skeletal muscle sections were subjected to histological, morphometric, biochemical and statistical studies.

Results: RB induced various histological changes in skeletal muscle in the form of congestion, atypical fibre, multiple fibroblast and dark nuclei. RB also caused a sig increase in area $\%$ collagen, area $\%$ of caspase 3 immunoexpression (IE), count of alpha smooth muscle actin IE(no I SMA) and count of +ve CD34 IE were recorded. Sig increase in the activity of interleukin-6(IL-6) and PI3K and AKT proteins. Concomitant administration with SO improved sig the previously mentioned changes.

Conclusion: It can be concluded that SO enhanced skeletal muscle regeneration in RB induced muscle injury expressed as a definite ameliorating effect to the induced inflammatory and degenerative changes.
\end{abstract}

Key Words: Antioxidant, : muscle, red bull, regeneration, sesame oil.

Revised: 28 August 2019, Accepted: 2 September 2019.

Corresponding Author: Amany Elsayed Mohammed Hamoud, MD, Department of Anatomy, Faculty of Medicine ,Cairo University, Tel.: 01020364428, E-mail: dramanyhamoud@gmail.com

ISSN:2536-9172, December 2019, Vol. 3, No. 2

\section{INTRODUCTION}

Energy drinks (Eds), including Red Bull, were introduced to United States markets in 1997. Consumption has increased worldwide mainly consumed by athletes and teenagers as they are seeking for increase their energy level (Totarro et al., 2018). They contain high level of caffeine ranged from $50-550 \mathrm{mg}$ /each can according to the brand, compared to $95 \mathrm{mg}$ for an eight-ounce cup of coffee (Kassab et al., 2018). Although moderate caffeine intake (up to $400 \mathrm{mg}$ /day for adults and $100 \mathrm{mg}$ /day for teens) is considered safe, higher volumes may increase the possibility of various health problems. Energy drinks contain also higher level of sugar to increase glucose energy level as well alertness to overcome fatigue, which might increase the risk for obesity, diabetes and dental caries (Salih et al., 2018).

The plant sesame is a well-known medicinal plants that is used in alternative medicine in treatment of many diseases (Alsallami and Alaauldeen, 2017). Seasme oil (SO) has been known to have anti-inflammatory and antioxidant properties, which makes it effective for reducing atherosclerosis and the risk of cardiovascular disease.
Recent studies indicate that quadriceps muscle weakness and dysfunction is directly related to oxidative stress and SO is a natural product with excellent antioxidative property (Hsu et al., 2016).

Owing to the lack of sufficient data on the effect of neither Red Bull nor Sesame Oil on skeletal muscle regeneration. Therefore the aim of the present study was to study the possible protective role of SO on skeletal muscle regeneration in Red Bull experimentally induced injury.

\section{MATERIALS AND METHODS}

\section{Animals:}

The current study was carried out on 20 adult male albino rats aged three to five months and weighing about 150-200 grams. The rats were obtained from Animal House of Kasr -Alainy, Faculty of Medicine, Cairo University. Rats were housed for one week for environmental adaptation under standard laboratory conditions at $22-24^{\circ} \mathrm{C}$ with 12 hours lightldark cycle. They were fed on a constant adequate nutrition diet and allowed free access to drinking water ad libitum. The experimental work was conducted in accordance with the guidelines of the Animals Committee at Cairo University. They were housed in cages, five 
rats/cage. The rats were divided into four groups as follow (five rats each):

- $\quad$ Group I (Control group): The rats received 7.5 $\mathrm{ml}$ saline using a gastric tube daily for four weeks.

- Group II (SO group): The rats received SO (Seed Crop Department, Ministry of Agriculture, Giza, season 2018) by a gastric tube, at a dose of $4 \mathrm{ml} / \mathrm{kg}$ daily for four weeks (Hsu et al., 2016).

- Group III (RB group): Rats received RB, one of the commonly used Eds available in local market (11-g sucrose, 32-mg caffeine, 400-mg taurine, 8-mg niacin, 2-mg pantothenic acid, 2-mg vitamin B6 and 2- $\mu \mathrm{g}$ vitamin B12 per $100 \mathrm{ml}$ ) (Roldán et al., 2017) at a dose (equivalent to $5 \mathrm{ml}$ ) daily for four weeks using gasrtic tube (Ayoub and Elsherbiny, 2016). This dose for rats was equivalent to the human dose conversion tables (Akande et al., 2011).

- $\quad$ Group IV (RB +SO Group): The rats received $\mathrm{RB}$ at a dose (equivalent to $5 \mathrm{ml}$ ) daily and $\mathrm{SO}$, at a dose of $4 \mathrm{ml} / \mathrm{kg}$ by a gastric tube daily for four weeks.

\section{Methods:}

Chemicals: Red bull is one of the commonly used EDs available in local market was used in this study. Ingredients: (11-g sucrose, 32-mg caffeine, 400-mg taurine, 8-mg niacin, 2-mg pantothenic acid, 2-mg vitamin B6 and 2- $\mu \mathrm{g}$ vitamin $\mathrm{B} 12$ per $100 \mathrm{ml})^{[8]}$.

SO (Seed Crop Department, Ministry of Agriculture, Giza, season 2018).

All rats were sacrificed by cervical dislocation (Iranpour and Kheiri 2016) using IP injection of phenobarbitone sodium (60 mg/kg) (Ozmen et al. 2002). Gastrocnemius muscle was exposed and muscle specimens were placed in $10 \%$ formol saline. for 48 hours. Paraffin blocks and $5 \mu \mathrm{m}$ thick sections were prepared. Sections were subjected to:

\section{Histological study:}

Hematoxylin and eosin (H\&E) stain (Kiernan 2001) and Masson's trichrome stain (Bancroft and Gamble 2008).

\section{Immunohistochemical Study:}

- Caspase 3 immunostaining (Bressenot et al., 2009): the marker for apoptosis. $7 \mathrm{ml}$ of rabbit polyclonal Ab (RB-1197-R7) (Lab Vision Corporation, USA) was prediluted ready to use solution stored at $2-8^{\circ} \mathrm{C}$. The $+v e$ tissue control was a specimen of human tonsil. Caspase 3 + ve cells showed cytoplasmic reaction. On the other hand, one of the muscle sections was used as a negative control by passing the step of applying the primary antibody.

- Anti-alpha smooth muscle actin ( $\alpha$-SMA) immunostaining (Elia et al., 2012): The marker for this antibody stains smooth muscle cells in vessel walls, gut wall, myometrium and myoepithelial cells. Anti-alpha smooth muscle actin antibody (Rabbit polyclonal antibody) (ab5694) was used at a concentration $0.5-2 \mu \mathrm{g} / \mathrm{ml}$. Perform heat mediated antigen retrieval before commencing with IHC staining protocol. Glioma tissue sections were used as positive control specimens. Cellular localization is the cytoplasm. On the other hand, one of the muscle sections was used as a negative control by passing the step of applying the primary antibody.

- $\quad$ CD34 immunostaining (Pasut et al., 2012) is the marker for hematopoietic progenitor cells, small vessel endothelium (15) and satellite cells of skeletal muscle (16) of a variety of tissues. CD34goat polyclonal Ab (SigmaAldrich Chemie Corporation laboratories, Germany, catalogue ID SAB4300690). The sections were treated with $\mathrm{CD} 34$, at $5-15 \mu \mathrm{g} / \mathrm{ml}$ ready to use at room temperature. Cellular localization is the cell membrane. Tonsil sections were used as positive control specimens. On the other hand, one of the muscle sections was used as negative control by passing the step of applying the primary antibody.

\section{Morphometric study:}

The area $\%$ of collagen fibers, that of caspase 3 IE, $\alpha$-SMA IE and count of CD34+ve cells were measured in Masson's trichrome and immunostained sections. These measurments were done in 10 high power fields (HPF) in control and experimental groups using interactive measurements menu.

\section{Biochemical parameters:}

IL-6 estimation: Tissue of skeletal muscle from the gastrocnemius muscle of the different groups were stored at $-80{ }^{\circ} \mathrm{C}$ and were homogenized in $10-20$ volumes with a buffer containing $1 \%$ sodium dodecylsulfate (SDS), 100 $\mathrm{mmol} / \mathrm{L}$ Tris $\mathrm{HCl}$ (pH6.8), $1 \mathrm{mmol} / \mathrm{L}$ phenylmethyl sulfonyl fuoride (PMSF), and $0.1 \mathrm{mmol} / \mathrm{L} \beta$-mer-captoethanol. IL-6 level was assessed in muscle tissue homogenate using RayBio1 Rat IL-1 $\beta$ and RayBio1 Rat IL6 ELISA Kits (Ray Biotech, Inc., USA). The steps were carried out according to the manufacturer's instructions (Ali 2016).

Western blotting analysis: Tissue homogenate was centrifuged at $12000 \times \mathrm{g}$ for $10 \mathrm{~min}$ at $4{ }^{\circ} \mathrm{C}$ and supernatant A was collected. The supernatant was centrifuged again at $4^{\circ} \mathrm{C}, 40000 \times \mathrm{g}$ for $10 \mathrm{~min}$, with the proper amount of membrane protein extraction reagent to obtain the supernatant after high-speed mixing using a vortex mixer after 5 seconds. Then, the sample was placed in an ice bath precipitation for 5-10 minutes, which was repeated 3 times to obtain the full extraction of protein. At $4^{\circ} \mathrm{C}, 40000 \times \mathrm{g} / 15$ min, supernatant B for PM GLUT4 was collected for the membrane protein solution. The protein concentration was determined by the BCA protein assay. For each sample, proteins were separated by electrophoresis via $10 \%$ sodium dodecylsulfate-polyacrylamide gel electrophoresis (SDS- 
PAGE). The gel was transferred to a nitrocellulose (NC) membrane (Bio-Rad Instruments, CA, USA) in transfer bufer containing $25 \mathrm{mmol} / \mathrm{L}$ Tris, $192 \mathrm{mmol} / \mathrm{L}$ glycine, and $20 \%$ methanol. The NC membranes were blocked using PBS containing $2 \%$ bovine serum albumin (BSA) and $0.05 \%$ Tween- 20 at $4{ }^{\circ} \mathrm{C}$ for $1 \mathrm{~h}$ at room temperature and incubated with primary antibody overnight. The following proteins were used for the supernatant A: Akt protein and Phosphoinositide 3-kinase (PI3-K) protein (Cell Signaling Technology, Danvers, MA) (Glass.2010).

\section{Statistical study:}

Quantitative data were summarized as means and standard deviations and compared using one-way analysis-of-variance (ANOVA). Any significant ANOVA was followed by post hoc Tukey test to detect which pairs of groups caused the significant (sig) difference. $P$-values $<0.05$ were considered statistically sig (Emsley). Calculations were made on Statistical Package of Social Science (SPSS) software version 16.

\section{RESULTS}

\section{Histological changes:}

Haematoxylin and Eosin (H\&E) stained sections: Longitudinal sections in skeletal muscle of control rats in group I showed cylindrical fibers arranged in a parallel pattern exhibiting peripheral pale nuclei and regular sarcoplasmic striations (Fig 1a). RB group revealed congested vessels surrounded by atypical fibers (Fig 1b), multiple fibroblasts between fibers exhibiting dark nuclei (Fig 1c). Other sections showed atypical muscle fibers exhibiting some striations in sarcoplasm, in addition to some fibroblasts among the fibers (Fig 2a). Transversely cut fibers demonstrated vacuolations and dark nuclei (Fig 2b). Few swollen transversely cut fibers were detected exhibiting a wide disorganized area of the sarcoplasm and dark nuclei (Fig 2c). RB+SO group showed less congestion, few fibroblasts in CT surrounding muscle fibers exhibiting separated myofibrils and striations (Fig 3a), multiple muscle fibers exhibited regular striations (Fig 3b) and transversely cut fibers exhibited few dark nuclei. Noncongested vessels were noticed (Fig 3c).

Masson's trichrome stained sections: In group I fine collagen fibers were seen between the muscle fibers (Fig 4a), in RB group widely distributed dense collagen fibers were detected between the muscle fibers (Fig 4b) and in $\mathrm{RB}+\mathrm{SO}$ group focal less dense collagen fibers were found between the muscle fibers (Fig 4c).

\section{Immunohistochemical changes:}

- Caspase 3 IE: In group I -ve IE was evident (Fig 5a), in group II multiple fibers demonstrated obvious + ve IE (Fig 5b) and in group III some fibers revealed less obvious +ve IE (Fig 5c).
- $\quad$ Alpha smooth muscle actin IE: In group I +ve IE was found in the wall of vessels and few flat cells (Fig 6a), in group II +ve IE was seen in the wall of multiple vessels and in few flat cells (Fig 6b) and in group III +ve IE was obvious in the wall of some vessels and in multiple flat cells (Fig 6c).

- CD34 IE: In group I -ve IE was found (Fig 7a), in group II few +ve flat cells were observed at the periphery of the fibers (Fig 7b) and in group III multiple +ve flat cells were mainly detected at the periphery of the fibers (Fig 7c)

\section{Morphometric results:}

The mean of area $\%$ of collagen fibers and +ve alpha smooth muscle actin IE was significantly increased in group II compared to groups I and III, while in group III a significant increase was found compared to group I. The mean area $\%$ of + ve caspase 3 and $+v e$ CD34 IE was found to be significantly increased in group II compared to group III (Table 1).

\section{Biochemical changes:}

- Inflammatory marker parameter changes (IL-6): In $\mathrm{RB}$ group a sig increase was found compared to the other two groups. In $\mathrm{RB}+\mathrm{SO}$ group a sig decrease was detected compared to RB group.

- $\quad$ PI3-K and AKT: Sig increase was found in both PI3-K and AKT proteins expression in RB group compared to the other two groups. While, a sig decrease was found in $\mathrm{RB}+\mathrm{SO}$ group compared to Ed group.

Table 1: Mean area $\%$ of collagen fibers, +ve caspase $3,+v e$ alpha smooth muscle actin and +ve CD34 IE.

\begin{tabular}{ccccc}
\hline Group & $\begin{array}{c}\text { Area\% of } \\
\text { collagen } \\
\text { fibers }\end{array}$ & $\begin{array}{c}\text { Count } \\
\text { of +ve } \\
\text { caspase3 IE }\end{array}$ & $\begin{array}{c}\text { Count of +ve } \\
\text { alpha smooth } \\
\text { muscle actin IE }\end{array}$ & $\begin{array}{c}\text { Count } \\
\text { of }+ \text { ve } \\
\text { CD34 IE }\end{array}$ \\
\hline $\begin{array}{c}\text { Group I } \\
\text { (control) }\end{array}$ & $0.19 \pm 0.03$ & - & $0.32 \pm 0.05$ & - \\
$\begin{array}{c}\text { Group } \\
\text { II(RB) }\end{array}$ & $11.34 \pm 3.21^{*}$ & $35.11 \pm 8.27^{*}$ & $1.33 \pm 0.14^{*}$ & $2.31 \pm 0.04^{*}$ \\
$\begin{array}{l}\text { Group III } \\
\text { (RB+SO) }\end{array}$ & $0.36 \pm 0.09^{\wedge}$ & $7.28 \pm 1.05$ & $2.19 \pm 0.25^{\wedge}$ & $7.92 \pm 1.33$ \\
\hline & & & & \\
- & sig P $\leq 0.05$ & & \\
& $*$ compared to groups I and III & \\
& $\wedge$ compared to groups I and II
\end{tabular}

Table 2: Mean values of IL-6, PI3-K and AKT proteins in different groups:

\begin{tabular}{cccc}
\hline Group & IL-6 & PI3-K & AKT \\
\hline $\begin{array}{c}\text { Group I } \\
\text { (control) }\end{array}$ & $1.02 \pm 0.2$ & $1.00 \pm 0.02$ & $1.03 \pm 0.09$ \\
Group & $6.3 \pm 1.57^{*}$ & $4.6 \pm 1.02^{*}$ & $6.5 \pm 0.54^{*}$ \\
II(RB) & & & \\
Group III & $2.5 \pm 0.09^{\wedge}$ & $2.06 \pm 0.07$ & $3.4 \pm 0.21^{\wedge}$ \\
(RB+SO) & & & \\
\hline & \multicolumn{2}{r}{ *sig compared to all groups. } \\
• & \multicolumn{1}{c}{ sig compared to RB group. }
\end{tabular}



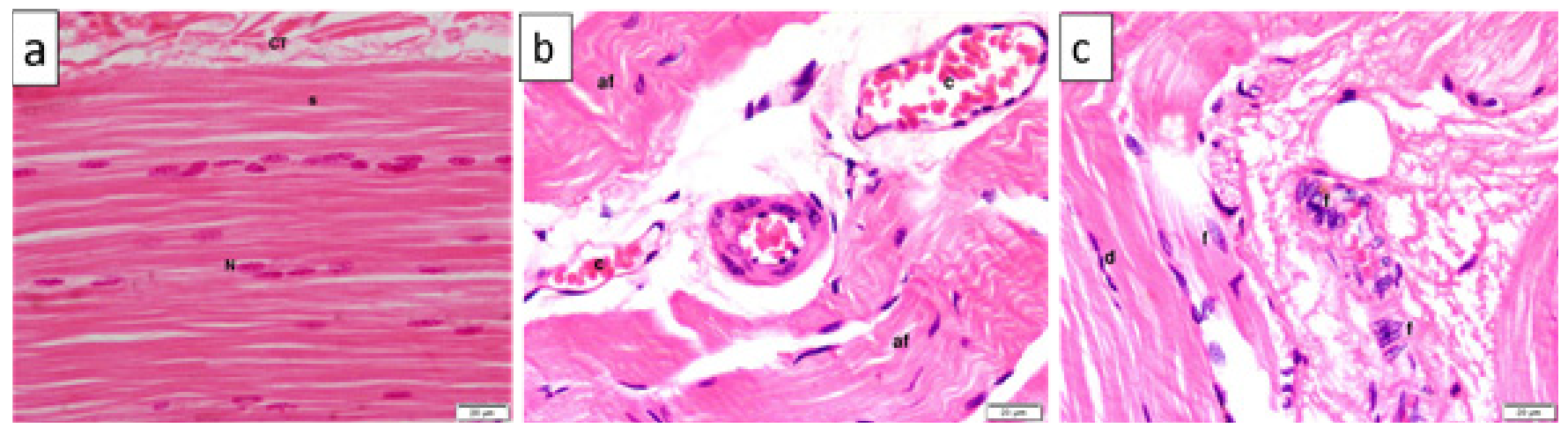

Fig. 1: Section in the skeletal muscle of a rat in control group stained by H\&E showing: (a) fibers exhibiting peripheral nuclei (N) and obvious striations (s) in sarcoplasm. Note connective tissue (CT) around the muscle fibers. (b) RB group showing congested vessels (c) surrounded by atypical fibers (af). (c) RB group showing multiple fibroblasts (f) between fibers exhibiting dark nuclei (d).

(H\&E,x 400)
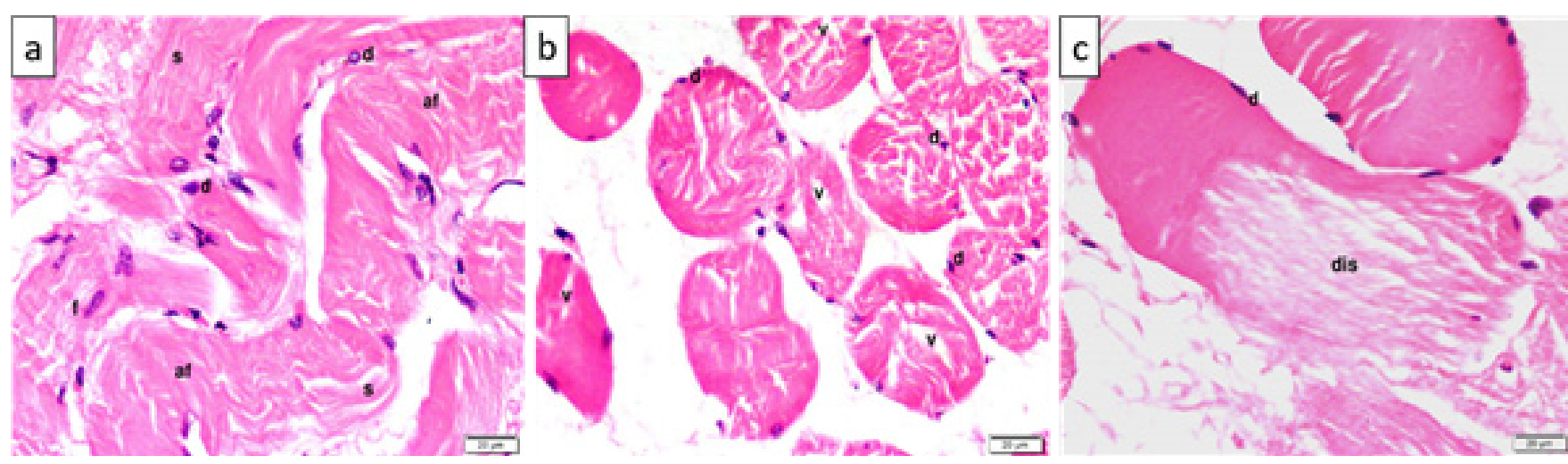

Fig. 2: Section in the skeletal muscle of rats in the RB group stained by H\&E showing: (a) atypical muscle fibers (af) exhibiting some striations (s) in sarcoplasm and dark nuclei (d), in addition to some fibroblasts (f) among the fibers. (b) transversely cut fibers exhibiting vacuolations (v) and dark nuclei (d). (c) a swollen transversely cut fiber exhibiting a wide disorganized area of the sarcoplasm (dis) and dark nuclei (d).

(H\&E, x 400).
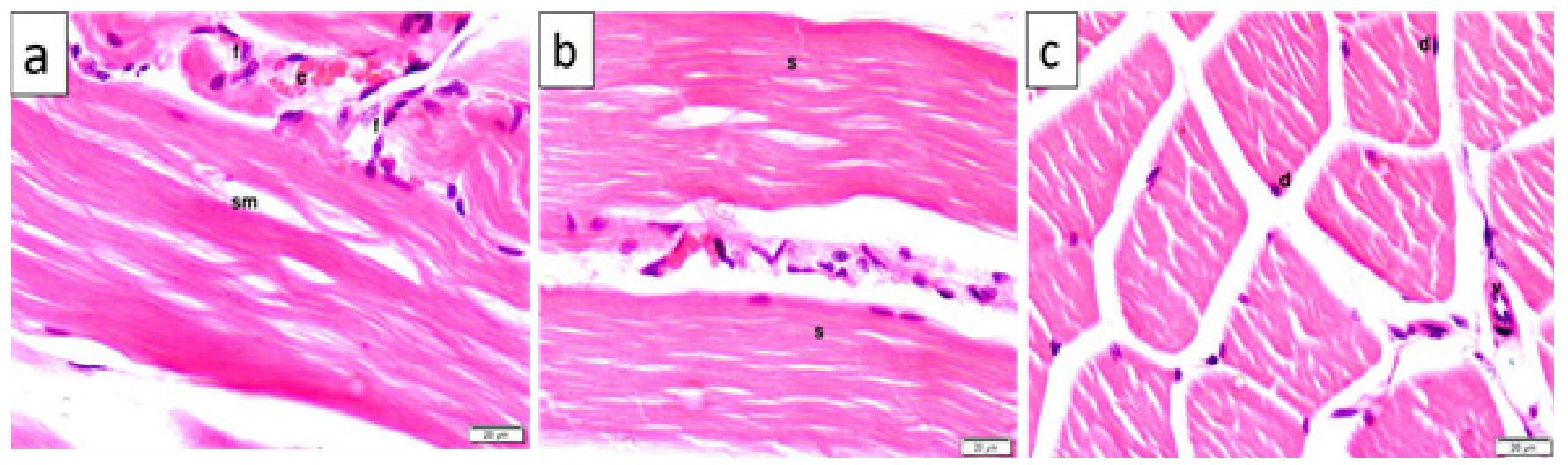

Fig. 3: Section in the skeletal muscle of rats in RB+SO group stained by H\&E showing: (a) less congestion (c), few fibroblasts (f) in CT surrounding a muscle fiber exhibiting separated myofibrils(sm) and striations.(b)two muscle fibers exhibiting regular striations(s). (c) transversely cut fibers exhibiting few dark nuclei (d). Note a non congested vessel (v).

$(H \& E, x$ 400) 

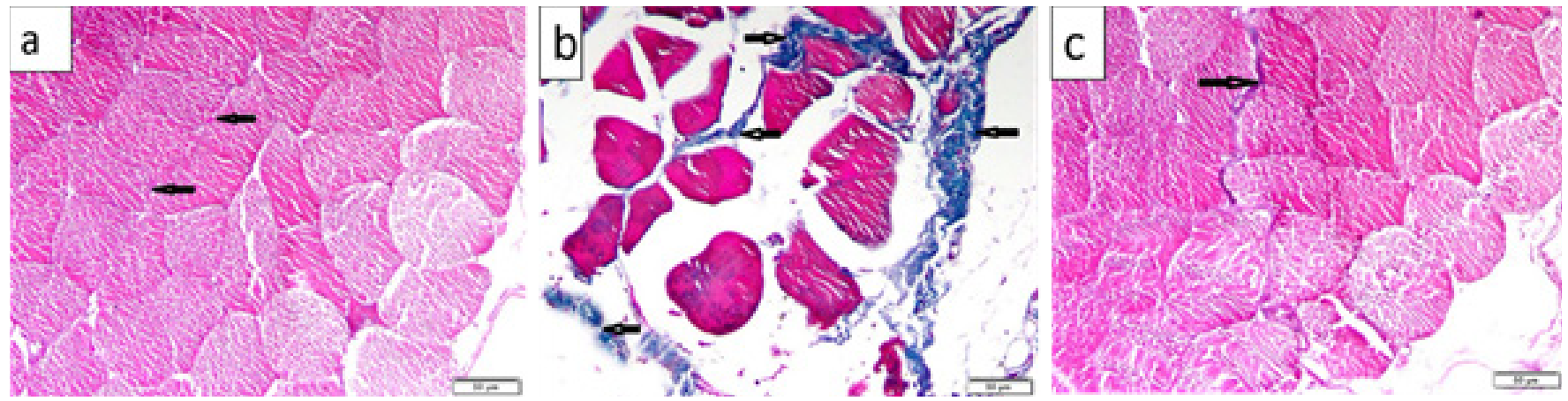

Fig. 4: Section in the skeletal muscle of a rat in Masson stained section showing: (a) control group showing fine collagen fibers (arrows) between the muscle fibers. (b) RB group showing widely distributed dense collagen fibers (arrows) between the muscle fibers. (c) RB+SO group showing focal less dense collagen fibers (arrows) between the muscle fibers.

(Masson's trichrome, x 200).

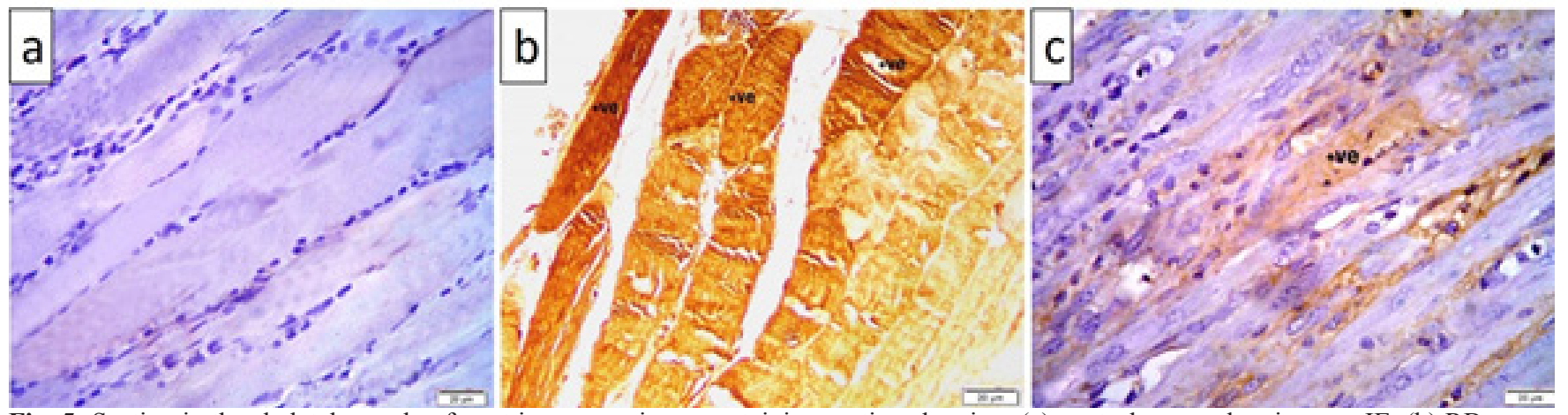

Fig. 5: Section in the skeletal muscle of a rat in caspase immunostaining section showing: (a) control group showing -ve IE. (b) RB group showing multiple fibers demonstrating obvious +ve IE (+ve). (c) RB+SO group showing some fibers demonstrating less obvious +ve IE (+ve).

(Masson's trichrome, x 200)
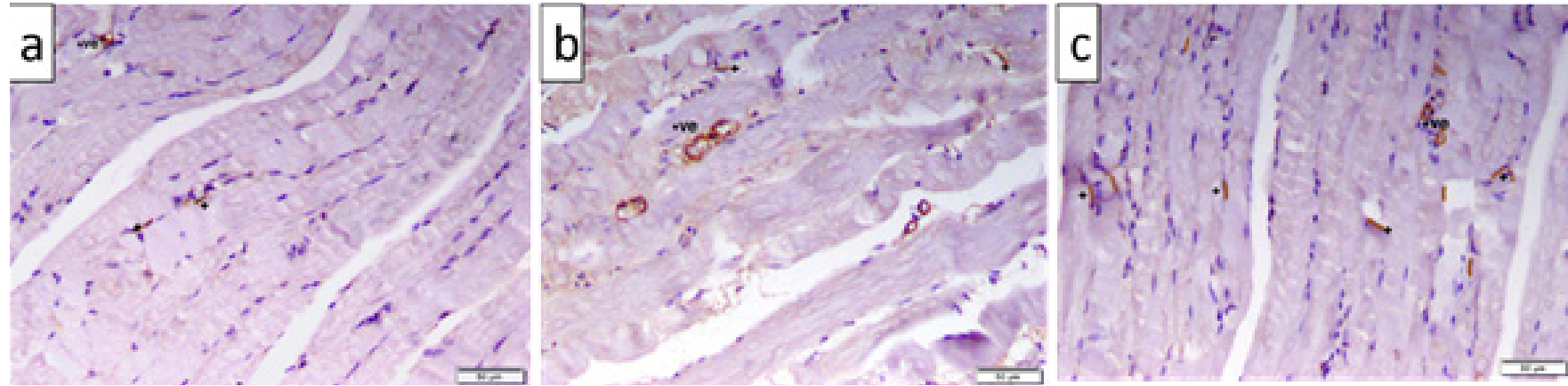

Fig. 6: Section in the skeletal muscle of a rat in a SMA immunostaining section showing: (a) control group showing +ve IE in the wall of a vessel and few flat cells (+ve). (b) RB group showing +ve IE in the wall of some vessels and in few flat cells $(+v e)$. (c) RB+SO group showing $+\mathrm{ve}$ IE in the wall of few vessels and in multiple flat cells $(+\mathrm{ve})$.

( $\alpha$ SMA immunostaining, $\mathrm{x} 200$ )
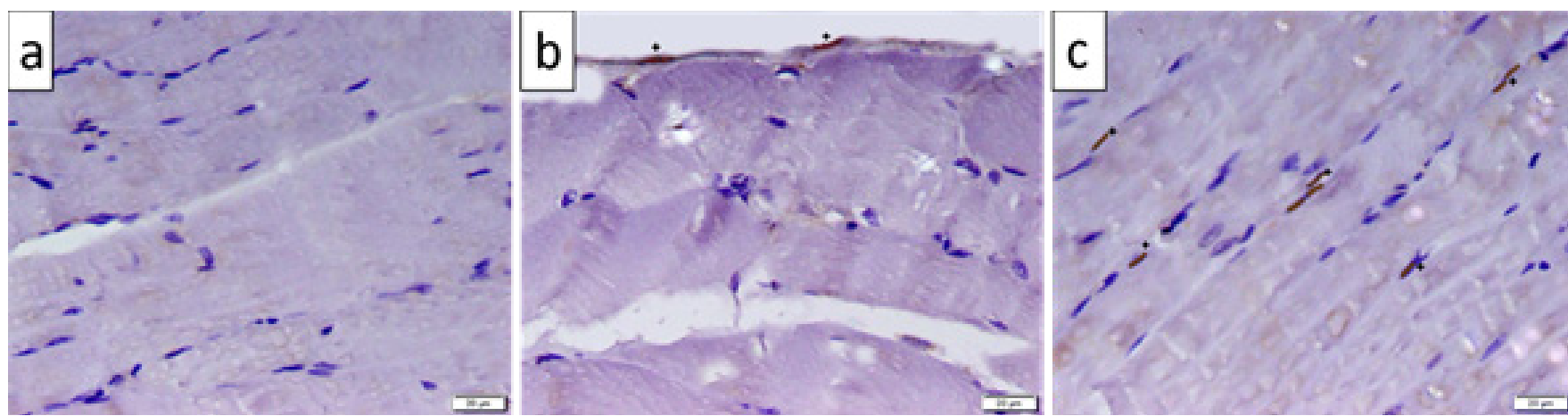

Fig 7: Section in the skeletal muscle of a rat in CD34 immunostaining section showing: (a) control group showing -ve IE (b) RB group showing few + ve flat cells $(+)$ at the periphery of the fiber. (c) $\mathrm{RB}+\mathrm{SO}$ group showing multiple + ve flat cells $(+)$ mainly at the periphery of the fiber.

(CD34 immunostaining, $\mathrm{x} 400$ ). 


\section{DISCUSSION}

The aim of the present study was designed to elucidate the possible ameliorative role of SO on the skeletal muscle regeneration in $\mathrm{RB}$ induced skeletal muscle injury of adult male albino rat. Amelioration of skeletal injury was evidenced by histological and immunohistochemical results and was confirmed by morphometric and biochemical results.

In the present study, in the $\mathrm{RB}$ group revealed various histological changes in the form of vacuolations, separation of myofibrils, swollen muscle fibres and congestion. These previous changes were indicative of degenerative changes. The latter changes might be due to the inadequate oxygen supply and the exchange of metabolites and other inflammatory mediators resulting in enlarged and hypertrophied fibers (Hassan et al., 2009). In accordance, the histopathological changes induced by chronic consumption of Power Horse one of the energy drinks for 4 weeks on the structure of pancreas and fundic mucosa of stomach in adult male albino rats was studied, and they attributed these changes to caffeine effect as it elevates levels of both tumor necrosis factor alpha (TNF- $\alpha$ ) and inducible nitric oxide synthase (iNOS) and increased oxidant stress (Ayuob and ElBeshbeishy, 2016).

Swollen muscle fibres existence can be related to, a sig higher expression of the PI3K/AKT proteins was recorded in the RB group. The PI3K/Akt signaling pathway plays an important role in regulating muscle metabolism. Activation of the PI3 kinase pathway can induce skeletal muscle hypertrophy, defined as an increase in skeletal muscle mass. Akt is a serine-threonine protein kinase that can induce protein synthesis and block the transcriptional upregulation of key mediators of skeletal muscle atrophy and subsequently increase in the muscle size (Glass. 2010).

In the current work many fibroblasts, dark nuclei and congestion were noticed in the RB group, and that was confirmed by sig increase in IL- 6 as inflammatory marker. Congestion observed in the present work could be related to the acute inflammatory response, followed by degenerative changes (Gillani et al., 2012). Tissue injury as a result of inflammatory response could lead to tissue death, followed by replacement of necrotic tissue by fibrous tissue (Youssef et al., 2015).

Dark nuclei which was obvious in RD group, and confirmed both by +ve IE in caspase 3 IE and morphometrically by sig increase in the area $\%$ of $+v e$ caspase IE. Going with, activation of an apoptotic process might affect the viability of the entire fiber (Sandari et al., 1998).

Dense collagen fibres were found in RB group which was confirmed by sig increase in area $\%$ of collagen fibers, which can be explained by the direct toxic effect of caffeine (Mubark et al., 2012). Recently, Munteanu et al (2018) studied the occurrence of negative effects of RD on the myocardium, and he correlated it to collagen accumulation in the myocardium.

In the present work, increased +ve $\alpha$ SMA IE and few CD34 + ve cells were detected in RB group, $\alpha$ SMA IE is an indicator of an attempt at muscle regeneration in response to injury. CD34 is considered the marker for muscle progenitor cells and satellite unipotant stem cells, which was supported by (Alfaro et al. 2011).

Concerning changes in SO treated group, regular muscle striations with less congestion were found compared to RB group, that was confirmed and related to the sig decrease in IL-6 value. In support, it was postulated that protective role of SO might be due to its potent ability to suppress oxidative stress, inflammation and antiapoptotic role (Woo., 2019). However, still some dark nuclei and separation of the myofibrils were residual, but less obvious +ve caspase IE and sig decrease in +ve caspase IE. That might be related to the dose and duration issues, as four weeks duration seemed to be insufficient for SO supplementation to start gaining complete recovery.

Minimal collagen fibers were detected in the SO group confirmed by a sig decrease in the mean area $\%$ of collagen fibers, and $\mathrm{Pi} / \mathrm{AKt}$ proteins expression compared to $\mathrm{RD}$ group. This confirmed the antifibrotic role of SO which was in agreement with other authors, who investigated the antifibrotic potential role of SO. They found that SO inhibiting cardiac fibroblast proliferation and blocking transforming growth factor (TGF- $\beta 1$ ) signaling cascade as transforming growth factor- $\beta 1$ (TGF- $\beta 1$ ) is one of the strongest pro-fibrotic factors that can induce fibroblasts proliferation, differentiation and collagen synthesis (Zaho et al., 2015).

In the present work, increased +ve $\alpha$ SMA IE and multiple CD34 +ve cells were detected in SO group. Results showed statistically sig increase in $\alpha$ SMA IE and count of CD34+ve cells in SO group compared to RB group denoting activated regeneration in SO group, which might be explained by enhanced migration of SCs to muscle tissue exposed to injury (Alfaro et al. 2011). It was considered that CD34 in addition of being a stem cell marker might play an important role in the stem cell activity. It was added that satellite cells within adult skeletal muscle are an enriched population of CD34+ve cells (Passut et al., 2012). It was postulated that activation of muscle precursor cells is an important determinant for the efficiency of muscle regeneration. It was added that the main source of muscle precursor cells are satellite cells, which proliferate and migrate to the injured site ( $\mathrm{Mu}$ et al., 2010). Therefore, local SCs were documented as a promising treatment for different diseases (Zaho et al., 2013). 


\section{CONCLUSION}

In can be concluded that SO enhanced skeletal muscle regeneration in $\mathrm{RB}$ induced muscle injury expressed as a definite ameliorating effect to the induced inflammatory and degenerative changes.

\section{CONFLICT OF INTEREST}

There are no conflicts of interest.

\section{REFERENCES}

1. Totaro M, Avella M, Giorgi S, Casini B, Tulipani A, Costa AL, Frendo L, Valentini P1, Lopalco PL, Privitera G, Baggiani A. Drinks consumption and related lifestyle among students of two Italian high schools. Ann Ig. 2018;30(6): 509-516.

2. Kassab, A., Tawfik, S. Effect of a caffeinated energy drink and its withdrawal on the submandibular salivary gland of adult male albino rats: A histological and immunohistochemical study. Egyptian Journal of Histology 2018; 41(1),11-26.

3. Salih NA, Abdul-Sadaand IH, Abdulrahman NR. Histopathological effect of energy drinks (Red Bull) on Brain, Liver, Kidney, and Heart in Rabbits. Med J Babylon 2018;15:16-20.

4. Alsallami, Alaauldeen. Effect of Sesame Oil on Male Rats Treated with Acrylamide in some Physiological and Hormonal Blood Criteria. International Journal of Current Pharmaceutical Review and Research 2017; 8. 134-140.

5. Hsu DZ, Chu PY, Jou IM. Enteral sesame oil therapeutically relieves disease severity in rat experimental osteoarthritis. Food Nutr Res. 2016; 60:29807.

6. Roldán $\mathrm{M}$, Echeverry-Alzate V, BühlerKM, Sánchez-Diez IJ, Calleja-Conde J, Olmos P, Boehm SL, Maldonado R, de Fonseca FR, Santiago C, Gómez-Gallego F, Giné E, LópezMoreno JA. Red Bull energy drink increases consumption of higher concentrations of alcohol. Addiction Biology 2018; 23: 1094-1105.

7. Ayuob N, ElBeshbeishy R. Impact of an Energy Drink on the Structure of Stomach and Pancreas of Albino Rat: Can Omega-3 Provide a Protection? 2016; 11(2): e0149191.

8. Akande IS, Banjoko OA Assessment of biochemical effect of "Power Horse" energy drink on hepatic, renal and histological functions in Sprague Dawley rats. Ann Rev Res Biol.2011; 1(3): 45-56.

9. Iranpour FG, Kheiri S. Coadministration of calcium chloride with lead acetate can improve motility of cauda epididymal spermatozoa in Swiss white mice. Int J Reprod. BioMed. 2016; 14(2): 141-144

10. Ozmen J, Bobryshev YV, Lord RS, Ashwell KW. Identification of dendritic cells in aortic atherosclerotic lesions in rats with diet induced hypercholesterolaemia. Histol Histopathol. 2002; 17: 223-237.

11. Kiernan JK. Histological and Histochemical methods. In: Theory and practice. 3rd ed, Arnold Publisher, London, New York and New Delhy 2001; 111-162.

12. Bancroft JD, Gamble M. Connective tissue stains. In: Theory and Practice of Histological Techniques, sixth edition. Elsevier Health Sciences, Churchill Livingstone, Edinburgh, London, Oxford, New York, Philadelphia, St Louis, Sydney and Toronto 2008:161-186.

13. Bressenot A, Marchal S, Bezdetnaya L, Garrier J, Guillemin F, Plénat F. Assessment of Apoptosis by Immunohistochemistry to Active Caspase-3, Active Caspase-7, or Cleaved PARP in Monolayer Cells and Spheroid and Subcutaneous Xenografts of Human CarcinomaJ Histochem Cytochem. 2009; 57(4): 289-300

14. Elia A, Charalambous F, Georgiades P. New phenotypic aspects of the decidual spiral artery wall during early post-implantation mouse pregnancy. Biochem Biophys Res Commun 2011; 416:211-216.

15. Pasut A, Oleynik P, Rudnicki MA. Isolation of muscle stem cells by fluorescence activated cell sorting cytometry. Methods Mol Biol 2012; 798:53-64

16. Ali AA, El-Zaitony AS, Al-Haleem ENA. Evaluation of Therapeutic Efficacy of Vinpocetine in Adjuvant Induced Arthritis Model in Rats. J Pain Manage Med. 2016; 2: 115-125.

17. Emsley R, Dunn G, White I. Mediation and moderation of treatment effects in randomized 
controlled trials of complex interventions. Stat Methods Med Res. 2010; 19(3): 237-270.

18. Hassan NF, El-Bakry NA, Shalaby NM, Ghobara MM, Bayomi NA. Histological Study of the Effect of Simvastatin on the Skeletal Muscle Fibers in Albino Rat and the Possible Protective Effect of Coenzyme Q 10. J Histol.2009; 31: 216-226.

19. Gillani S, Cao J, Suzuki T, Hak DJ. The effect of ischemia reperfusion injury on skeletal muscle. Injury 2012; 43: 670-675.

20. Youssef MF, Zickri MB, Gamal M, Yassin N, ElAI LA, Elhadary N. Effect of Exercise Training on Endogenous Stem Cells Activation in Ischemia Reperfusion Induced Skeletal Muscle Injury: A Physio- Histological Study. J Cytol Histol.2015; 6: 339 .

21. Mubarak R Effect of Red Bull energy drink on rats submandibular salivary glands (Light and Electron microscopic study). Journal of American Science 2012; 8(1): 366-372.

22. Sandri M, Minetti C, Pedemonte M, Carraro U. Apoptotic myonuclei in human Duchenne muscular dystrophy. Lab Inv.1998; 78: 1005-1016.

23. Glass DJ. PI3 kinase regulation of skeletal muscle hypertrophy and atrophy. Curr Top Microbiol Immunol. 2010; 346: 267-78.
24. Alfaro LA, Dick SA, Siegel AL, Anonuevo AS, McNagny KM, Megeney LA, Cornelison DD, Rossi FM. CD34 promotes satellite cell motility and entry into proliferation to facilitate efficient skeletal muscle regeneration. Stem Cells 2011 (12): 2030-2041.

25. Pasut A, Oleynik P, Rudnicki MA. Isolation of muscle stem cells by fluorescence activated cell sorting cytometry. Methods Mol Biol. 2012; 798: 53-64.

26. Mu X, Urso ML, Murray K, Fu F, Li Y. Relaxin regulates MMP expression and promotes satellite cell mobilization during muscle healing in both young and aged mice. Am J Pathol. 2010; 177: 2399-2410.

27. Zhao X, Huang L. Cardiac stem cells: A promising treatment option for heart failure. Exp Ther Med. 2013; 5: 379-383.

28. Woo M, Han S, Song YO. Sesame Oil Attenuates Renal Oxidative Stress Induced by a High Fat Diet. Prev Nutr Food Sci. 2019; 24(2): 114-120.

29. Zhao M, Zheng S, Yang J, Wu Y, Ren Y, Kong $X$, Li W, Xuan J. Suppression of TGF- $\beta 1 /$ Smad signaling pathway by sesamin contributes to the attenuation of myocardial fibrosis in spontaneously hypertensive rats. PLoS One. 2015; 10(3): e0121312. 
الملخص العربى

الدور الوقائي المحتمل لزيث السمسم على تجديا العضلات في الإصابة المستحثة بمشروب الطاقة:

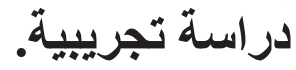

رشا عبا الخالق عطية رضوان 1 ـ أماني السيد محمد موسي حمود2

1,2مدرس بقسم التشريح و الأجنة كلية الطب جامعة القاهرة- مصر

مقدمة: مشروبات الطاقة مثل الريد بُول ظهرت فى أسواق الو لايات المتحدة في عام 1997. وقد ز اد الإستهلاك في جميع أنحاء

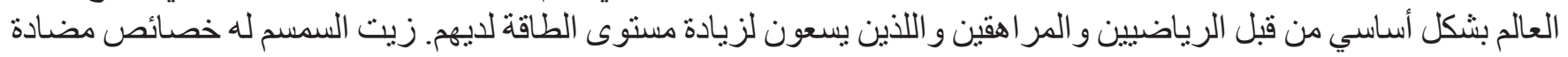
للإلتهابات ومضادة للأكسدة. الههف من الدراسة: تم تصميم الدراسة الحالية لدراسة الدور الوقائي الدحتمل لزيت السمسم على تجديد العضلات الهيكلية في إصابة ريد بُول التجريبية.

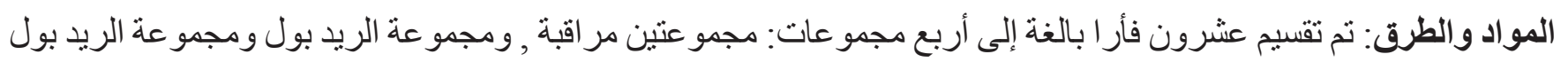

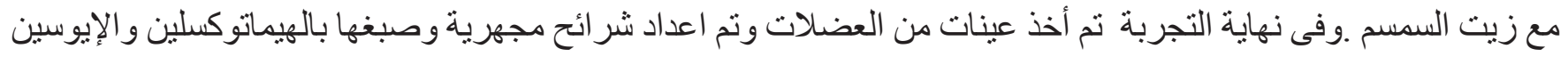

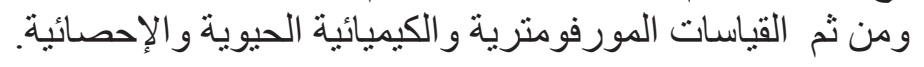

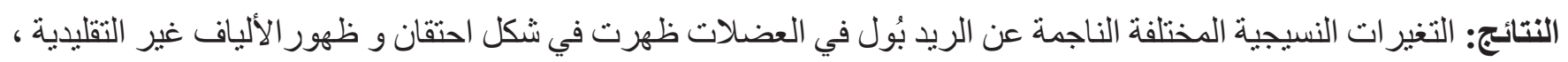

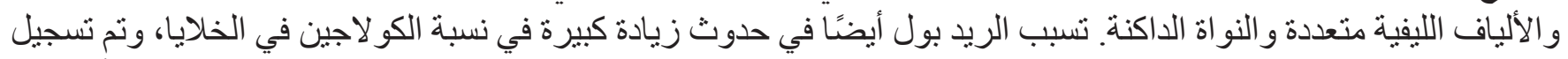

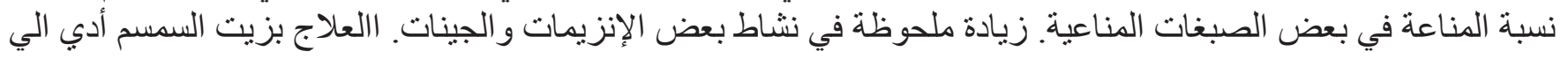
تحسين التغييرات المذكورة سابقا.

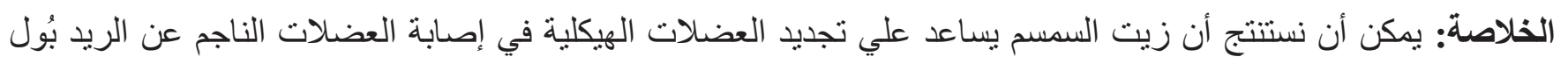
معبر عنه بتخفيف واضح للتغير أن ات الإنتهابية المستحثة. 